Instituto Internacional de Investigación y Desarrollo Tecnológico Educativo INDTEC, C.A.

DOI: https://doi.org/10.29394/Scientific.issn.2542-2987.2018.3.8.0.7-18

OAI-PMH: http://www.indteca.com/ojs/index.php/Revista Scientific/oai

\title{
La Sistematización de Experiencias y Saberes desde la Ontología hacia la Praxeología de la Investigación Educativa en el Contexto Universitario
}

\author{
PhD. Mario Morales Guerrero \\ Universidad Nacional Experimental de la Gran Caracas, UNEXCA \\ moralmario@gmail.com \\ Caracas, Venezuela
}

\section{Editorial}

En la actualidad en el contexto de las ciencias sociales, específicamente en la praxis de la educación universitaria es necesario visualizar la metodología de trabajo de investigación que se implementa en los seminarios de investigación donde se sugiere la sistematización de experiencias y saberes como una alternativa de la investigación social que consiste en la sistematización de la cotidianidad con una visión del quehacer científico bajo el paradigma del fenómeno cultural, histórico y el dialogar de la comunidad. Esta metodología, desde una perspectiva de lo praxeológico - gnoseológico, apunta a reconocer la riqueza de conocimientos generados en la práctica, recuperar aquellos que han sido valiosos y pertinentes en diversos contextos y hacerlos entendibles y amigables para que otros puedan valerse de estas vivencias. Se parte de hacer un recorrido por esta metodología de trabajo y por compartir la implementación que se logra desde el plano ontológico de la realidad para enriquecer la trayectoria formativa de los estudiantes conjuntamente a los actores sociales en escenarios comunes para los protagonistas lo que implica redimensionar el uso del lenguaje dando lugar a una reinterpretación de los códigos lingüísticos, generándose una reconstrucción del sentir y del quehacer a través de los sentidos colectivos.

La trascendencia de la sistematización podría apreciarse como una forma específica de investigación que permite la recuperación de los saberes y conocimientos que han sido eficaces para intervenir en los procesos de enseñanza y aprendizaje.

La presente reflexión emerge desde la vivencia del autor y su compartir en el ámbito de la investigación social teniendo como eje trascendental a la educación universitaria es por eso que a través de estas líneas se pretende exponer la metodología de trabajo que se está desarrollando en el seminario de investigación que imparte a nivel universitario en la cual se han incorporado el desarrollo de las competencias investigativas de los estudiantes de los 
postgrados, la sistematización de experiencias como eje vertebrador y articulador de la praxis investigativa. El seminario se presenta como una instancia reflexiva y de integración de los saberes básicos y específicos del docente investigador social. Tiene como propósito cerrar el proceso de la formación de los seminarios donde el participante por medio de la articulación del constructo teórico que los estudiantes han incorporado a lo largo de su formación, con la situación concreta de enseñanza y de aprendizaje que se les plantea en la dialógica de los intercambios de saberes y seleccione su postura paradigmática para la creación de nuevas miradas socio vinculantes del hecho fenomenológico ,a partir de la reflexión, que luego les permitirá transformar el contexto bajo una mirada crítica.

En estos espacios, se propone la formación de ciclos reflexivos hermenéuticos los cuales consisten en insertarse en un espacio del saber donde el docente e Investigador Social tenga protagonismo y puedan elaborar una producción didáctica que se integre en una unidad temática que le haga sentir al escenario de la comunidad donde se levanten información por medio de estudios etnográficos ,porque el convivir es quien le dará sentido a el lenguaje a través de la interpretación de códigos lingüísticos, tal como lo señala Echeverría (2008): en los espacios iconográficos de sistematización de saberes, se desarrollan diálogos y experiencias constituido por aquellos espacios sociales donde es posible reconocer procesos educativos y producción de sentidos, y el aprendizaje que se da en contextos en los que existiendo una intencionalidad educativa por medio de la planificación de una propuesta pedagógica basadas en las experiencias de enseñanzaaprendizaje ocurren fuera del ámbito de la escolaridad.

\section{Investigación educativa y el hecho social como fenómeno}

Partiendo de la premisa que la Investigación en Educación, es todo un estudio genérico investigativo relacionado con la sociedad, sea investigación educativa o investigación sobre educación, donde el abordaje es macro y tiene como objeto de estudio a la educación, la propuesta de desarrollar acciones reflexivas dentro de un seminario de enfoque social, se encuadra dentro de lo que se denomina "investigación educativa", donde se apunta a los procesos de enseñanza y aprendizaje. La investigación educativa se realiza enmarcada en el proceso educativo, donde el foco está puesto: Sobre la práctica pedagógica, las prácticas docentes, las implicaciones sobre los aprendizajes, los planes de estudio, las formas de evaluación, las formas de comunicación 
e interacción en el aula, los estilos pedagógicos de los docentes, las formas de enseñanza, los estilos de aprendizaje, propuestas para mejorar los resultados académicos (Restrepo, Cubides, y Morales, 2012).

Parafraseando las posturas de Jara (2006): acerca de la sistematización de experiencias me atrevo a señalar que mientras que en el ejercicio usual del trabajo docente el saber sobre la transmisión no suele filtrarse en el caso de la formación docente es su objeto central, ya que es en torno al saber sobre la enseñanza y el trabajo docente que se estructuran los procesos de formación. De esta forma, se sugiere como contenido propio del sistema formador, la producción de saberes sobre la enseñanza, sobre el trabajo docente y sobre la formación.

Tal como lo afirma Jara (2008):

Muchas veces la sistematización de experiencias es confundida con la mera recopilación de datos o con la narración de eventos, o aún con la producción de una informe síntesis de una experiencia, las conceptualizaciones en torno a la sistematización de las experiencias, han ido generando interesantes puntos de reflexión en torno a su identidad específica (pág. 12).

\section{Una mirada reflexiva a la sistematización de experiencias}

Como lo podría señalar Rafael Echeverría en su postura del lenguaje ontológico o la ontología del lenguaje desde una perspectiva latinoamericana de abordaje investigativo a las prácticas de la enseñanza, por lo que se considera pertinente abordar su estudio desde la sistematización de experiencias, de manera de relevar experiencias y concepciones heterogéneas a través de diálogos y saberes, implementadas de acuerdo con las necesidades del contexto. La sistematización de experiencias como proceso, se deriva de las diferentes posturas y argumentaciones de algunos visionarios en materia teórica de Latinoamérica y que fue visualizada en un principio como forma de abordaje y reconstrucción de experiencias de educación popular para construir conocimiento en conjunto con los sujetos intervinientes, tal como lo pudo haber visto Freire, Maturana y el mismo Echeverría como elemento emancipador del hombre y como sinónimo de libertad en sí mismo y para sí mismo. En estos momentos, esta metodología de trabajo deja de ser exclusiva del contexto de la educación no formal para poder ser trabajada también en ámbitos donde la educación tiene un mayor grado de formalidad, y está más estructurada, como es el sistema educativo 
que persigue títulos académicos, estudios institucionales de organismos públicos y privados, ámbito donde se implementa actualmente para luego extenderla a otros contextos formativos.

Éstas, deben guiarse por unos objetivos y procedimientos apropiados y deben producir buenos resultados, demostrando su utilidad en el proceso de enseñanza y aprendizaje, haciendo hincapié fundamentalmente en la satisfacción de las necesidades de las personas a las que van dirigidas.

Barnechea y Morgan (2007a:10), explican que el desafío está en conseguir que estos procesos permitan comprender y explicar las situaciones enfrentadas en la práctica y producir conocimientos que orienten adecuadamente la acción futura, recurriendo a la reflexión, la interpretación crítica y los aportes teóricos como "instrumentos" que contribuyan a esta comprensión y explicación.

Es importante tener en cuenta dos cuestiones: que la sistematización de experiencias no es "evaluar", ya que el eje que orienta la producción de cono cimientos no está centrado en el proyecto y el cumplimiento de sus objetivos, sino en comprender los procesos que se desarrollan a partir de un proyecto para extraer aprendizajes que contribuyan a mejorar la práctica. (Barnechea y Morgan, 2007b:16). Y segundo, que no es "compilar información", sino producir una descripción consensuada, sobre la experiencia, una reconstrucción de su trayectoria a partir de la participación, la observación y los relatos de los sujetos intervinientes, donde las voces de los informantes serán escuchadas y sus experiencias serán sistematizadas. Y como en toda reconstrucción hay que reconocer que está presente la interpretación.

\section{La sistematización de experiencias una metódica dentro de los procesos investigativos}

Teniendo en cuenta, tal como se ha mencionado, que toda reconstrucción requiere interpretación.

El compromiso del investigador social y educativo está en la búsqueda de los significados que hace que se involucre activamente con el grupo que investiga, y sea consciente de los efectos que su presencia produce en el contexto.

En este sentido, se considera que el diálogo es fundamental, comprendido desde la perspectiva de Fierro, Fortoul y Rosas (1999): ya que es este ejercicio el que permite el pensamiento crítico a partir de la 
confrontación de ideas, conocimientos y convicciones de unos y otros. Así, se plantea que un docente que pretende reflexionar críticamente sobre su práctica no puede mantenerse al margen de las ideas, los conceptos y las experiencias educativas de otros.

En cuanto a lo metodológico, Barnechea y Morgan (2007c): plantean que el rigor proviene, por un lado, de hacer explícitos los sustentos (teóricos 0 no) de la práctica que se está reflexionando y, por otro, de la capacidad del/la sistematizador/a para mirarla críticamente, comprender lo que sucedió y fundamentar los conocimientos producidos al hacerlo.

\section{Las dimensiones de los procesos de sistematización}

La sistematización de experiencias, según Reyes (2008a): posee cuatro dimensiones.

Esta autora plantea que se hace necesario tomar en consideración los momentos que se describen en las, líneas posteriores con la intencionalidad de dar un orden al proceso reflexivo en la metódica de sistematizar los saberes.

Afirma que la dimensión ontológica, que aborda los ejes transversales educativos de ser y convivir, con énfasis en la axiología y valores que deberían prevalecer en un(a) educador(a) en los tiempos que corren. Para esta dimensión se tienen en cuenta los hechos culturales, los valores, las subjetividades, las creencias y las emociones, es decir, el sentir juega un papel importante en la sistematización. Esta dimensión se pone de relieve cuando se trabaja junto a los estudiantes con la autobiografía, el propio perfil como docente, la proyección a futuro, y cómo se considera que debe ser el rol profesional.

Asimismo, se enfoca en la dimensión metodológica, dado que es a través de herramientas metodológicas, técnicas e instrumentos vinculados a la metodología cualitativa es como se realiza la reconstrucción crítica de los aprendizajes por experiencia. Esto permite fortalecer sus conocimientos metodológicos vinculados al eje transversal educativo del hacer.

De igual manera señala a la dimensión epistemológica, donde se ubica la producción de conocimiento, que emerge de la experiencia, a partir del abordaje del eje transversal educativo "conocer", vinculado a la construcción crítica de nuevas categorías de análisis, partiendo de los contextos y cotidianidades alrededor de la experiencia sistematizada.

Y por último y no menos importante hace énfasis en la dimensión 
política, la cual considera sumamente relevante para el trabajo de sistematización, ya que permite problematizar para qué y para quién sistematizamos la experiencia. Es importante dejar claro que el objetivo de la del seminario es, tal como lo plantea Reyes (2008b): es facilitar la sistematización para transformar y transformarnos a través de la comprensión crítica de nuestras experiencias, que no es sólo nuestra, sino que atraviesa a todos los sujetos intervinientes.

Para el autor la sistematización de experiencias es una forma de hacer en el convivir, de transformar en la realidad ontológica apoyado de valores éticos y morales conjugados con las creencias compartidos de una comunidad transferible para la construcción de una ciudadanía, arraigada en saberes, diálogos y experiencias.

Palabras clave: educación; aprendizaje; enseñanza superior.

Fecha de Recepción: 16-03-2018 Fecha de Aceptación: 09-04-2018 


\section{The Systematization of Experiences and Knowledge from the Ontology towards the Praxeology of Educational Research in the University Context}

\section{Editorial}

Currently in the context of the social sciences, specifically in the practice of university education it is necessary to visualize the methodology of research work that is implemented in research seminars where the systematization of experiences and knowledge is suggested as an alternative to the social research that consists in the systematization of everyday life with a vision of scientific work under the paradigm of cultural and historical phenomenon and the dialogue of the community. This methodology, from a perspective of praxeological - gnoseological, aims to recognize the wealth of knowledge generated in practice, recover those that have been valuable and relevant in various contexts and make them understandable and friendly so that others can use these experiences. Be part of a journey through this work methodology and to share the implementation that is achieved from the ontological plane of reality to enrich the formative trajectory of the students together with the social actors in common scenarios for the protagonists, which implies resizing the use of language leading to a reinterpretation of linguistic codes, generating a reconstruction of feeling and doing through the collective senses.

The importance of systematization could be seen as a specific form of research that allows the recovery of knowledge and knowledge that has been effective to intervene in teaching and learning processes.

The present reflection emerges from the experience of the author and his sharing in the field of social research having as a transcendental axis to university education that is why through these lines is intended to expose the work methodology that is being developed in the seminar of research that imparts at the university level in which the development of the research skills of postgraduate students has been incorporated, the systematization of experiences as the backbone and articulator of the research practice. The seminar is presented as a reflexive and integrative instance of the basic and specific knowledge of the social research teacher. Its purpose is to close the process of the formation of seminars where the participant through the articulation of the theoretical construct that the students have incorporated throughout their training, with the concrete teaching and learning situation that arises in the dialogical exchange of knowledge and select its paradigmatic 
position for the creation of new socio-binding views of the phenomenological fact, from the reflection, which will then allow them to transform the context under a critical gaze.

In these spaces, the formation of hermeneutical reflective cycles is proposed, which consists of inserting oneself into a space of knowledge where the teacher and Social Researcher plays a leading role and can produce a didactic production that is integrated into a thematic unit that makes him feel at the stage of the community where information is collected through ethnographic studies, because living together gives meaning to the language through the interpretation of linguistic codes, as pointed out by Echeverría (2008): in the iconographic spaces of systematization of knowledge, dialogues and experiences are developed, constituted by those social spaces where it is possible to recognize educational processes and production of meanings, and the learning that takes place in contexts in which there is an educational intention through the planning of a pedagogical proposal based on the experiences of teaching-learning happen outside of the field of schooling.

\section{Educational research and the social fact as a phenomenon}

Starting from the premise that Research in Education is a generic research study related to society, be it educational research or research on education, where the approach is macro and has as object of study to education, the proposal to develop reflexive actions within of a seminar with a social focus falls within what is called "educational research", where the teaching and learning process is aimed at. Educational research is framed in the educational process, where the focus is on: pedagogical practice, teaching practices, implications on learning, study plans, forms of evaluation, forms of communication and interaction in the classroom, pedagogical styles of teachers, teaching methods, learning styles, proposals to improve academic results (Restrepo, Cubides, and Morales, 2012).

Paraphrasing the positions of Jara (2006): about the systematization of experiences I dare to point out that while in the usual exercise of teaching work knowledge about transmission is not usually filtered in the case of teacher training is its central objective, since that it is around knowing about teaching and teaching work that the training processes are structured. In this way, the content of the training system is suggested as the production of knowledge about teaching, about teaching work and about training. 
As stated by Jara (2008):

Many times the systematization of experiences is confused with the mere collection of data or with the narration of events, or even with the production of a synthesis report of an experience, the conceptualizations around the systematization of experiences, have been generating interesting points of reflection around their specific identity (p. 12).

\section{A reflexive look at the systematization of experiences}

As Rafael Echeverría could point out in his position on the ontological language or the ontology of language from a Latin American perspective of investigative approach to teaching practices, for which it is considered appropriate to approach his study from the systematization of experiences, in order to relieve experiences and heterogeneous conceptions through dialogues and knowledge, implemented according to the needs of the context. The systematization of experiences as a process, is derived from the different positions and arguments of some visionaries in Latin American theory and that was initially visualized as a way of approaching and reconstructing popular education experiences to build knowledge in conjunction with the subjects involved, as Freire, Maturana and Echeverría himself could have seen as the emancipating element of man and as synonymous with freedom in himself and for himself. At present, this work methodology ceases to be exclusive of the context of non-formal education to be able to be worked also in areas where education has a greater degree of formality, and is more structured, such as the educational system that pursues academic degrees, institutional studies of public and private organizations, where it is currently implemented and then extend it to other training contexts.

These should be guided by appropriate objectives and procedures and should produce good results, demonstrating their usefulness in the teaching and learning process, emphasizing fundamentally the satisfaction of the needs of the people to whom they are directed.

Barnechea and Morgan (2007a:10), explain that the challenge lies in getting these processes to understand and explain the situations faced in practice and produce knowledge that adequately guides future action, resorting to reflection, critical interpretation and the theoretical contributions as "instruments" that contribute to this understanding and explanation.

It is important to take into account two issues: that the systematization of experiences is not "evaluating", since the axis that guides the production of 
knowledge is not focused on the project and the fulfillment of its objectives, but on understanding the processes that they develop from a project to extract learnings that contribute to improve the practice. (Barnechea and Morgan, 2007b:16). And second, that it is not "compiling information", but producing a consensual description, about the experience, a reconstruction of its trajectory from the participation, the observation and the stories of the intervening subjects, where the voices of the informants will be heard and their experiences will be systematized. And as in any reconstruction we must recognize that interpretation is present.

\section{The systematization of experiences a methodical within the investigative processes}

Taking into account, as mentioned, that all reconstruction requires interpretation.

The commitment of the social and educational researcher is in the search of the meanings that makes him actively involved with the group he researches, and is aware of the effects that his presence produces in the context.

In this sense, it is considered that the dialogue is fundamental, understood from the perspective of Fierro, Fortoul and Rosas (1999): since it is this exercise that allows critical thinking based on the confrontation of ideas, knowledge and convictions of some and others. Thus, it is argued that a teacher who seeks to reflect critically on their practice can not stay out of ideas, concepts and educational experiences of others.

Regarding the methodological, Barnechea and Morgan (2007c): pose that the rigor comes, on the one hand, to make explicit the sustenance (theoretical or not) of the practice that is being considered and, on the other, of the capacity of the / the systematizer to look at it critically, understand what happened and base the knowledge produced in doing so.

\section{The dimensions of the systematization processes}

The systematization of experiences, according to Reyes (2008a): it has four dimensions.

This author states that it is necessary to take into consideration the moments described in the following lines with the intention of giving an order to the reflective process in the method of systematizing knowledge.

It affirms that the ontological dimension, which addresses the 
transversal educational axes of being and coexisting, with emphasis on the axiology and values that should prevail in an educator in these times. For this dimension, cultural facts, values, subjectivities, beliefs and emotions are taken into account, that is, feeling plays an important role in systematization. This dimension is highlighted when working together with the students with the autobiography, the profile as a teacher, the projection for the future, and how it is considered that the professional role should be.

Likewise, it focuses on the methodological dimension, given that it is through methodological tools, techniques and instruments linked to qualitative methodology that critical reconstruction of learning by experience is carried out. This allows strengthening their methodological knowledge linked to the educational transversal axis of doing.

Likewise, it points to the epistemological dimension, where the production of knowledge is located, which emerges from experience, based on the approach of the educational transversal axis "knowing", linked to the critical construction of new categories of analysis, starting from the contexts and daily life around the systematized experience.

And last but not least, it emphasizes the political dimension, which it considers highly relevant for the systematization work, since it allows to problematize for what and for whom we systematize the experience. It is important to make clear that the objective of the seminar is, as proposed by Reyes (2008b): it is to facilitate the systematization to transform and transform through the critical understanding of our experiences, which is not only ours, but crosses all the intervening subjects.

For the author, the systematization of experiences is a way of living together, of transforming into the ontological reality supported by ethical and moral values combined with the shared beliefs of a transferable community for the construction of a citizenship, rooted in knowledge, dialogues and experiences.

Keywords: education; learning; higher education.

Date Received: 16-03-2018

Date Acceptance: 09-04-2018 


\section{Referencias}

Barnechea, M., \& Morgan, M., De La Luz (2007a,b,c). El conocimiento desde

la práctica y una propuesta de método de sistematización de experiencias. Trabajo de investigación presentado para optar al Grado

Académico de Magíster en Sociología, Lima: Pontificia Universidad Católica del Perú. Recuperado de:

http://www.cepalforja.org/sistem/documentos/Conocimiento desde $\mathrm{pr}$ actica.pdf

Echeverría, R. (2008). Ontología del lenguaje. Chile: J-C-Sáez Editor.

Fierro, C., Fortoul, B., \& Rosas, L. (2008). Transformando la práctica docente: una propuesta basada en la investigación-acción. México D.F.: Editorial Paidós.

Jara, O. (2006). Para Sistematizar Experiencias. Brasília, D.F.: Ministério do Meio Ambiente. Recuperado de:

http://www.mma.gov.br/estruturas/168/ publicacao/168 publicacao300 12009115508.pdf

Jara, O. (2008). La Sistematización de Experiencias: Práctica y Teoría para otros Mundos Posibles. Bogotá: Talleres de Javegraf.

Restrepo, J., Cubides, C., \& Morales, O. (2004). Sistematización de la experiencia desarrollo humano y habilidades para la vida en el Proyecto Juventud Manizales 2000 y las instituciones asociadas al GIPA Manizales 1997-2002. Manizales, Colombia: Editorial Centro de Estudios Avanzados en Niñez y Juventud alianza de la Universidad de Manizales y el CINDE., págs. 241.

Reyes, A. (2008a,b). La sistematización de experiencias y la visión y emergente del hecho educativo. Ponencia presentada en el Encuentro Internacional sobre Sistematización. República de Venezuela: Universidad Bolivariana de Venezuela (UBV). 